\title{
Assessment on Production, Processing and Marketing Status of Beeswax in Kafa Zone, Southern Nations Nationalities and Peoples Region (SNNPR), Ethiopia
}

\author{
Tesfu Shegaw*, Tewabe Edimew \\ Email address: \\ tesfushegaw68@gmail.com (T. Shegaw), tewa12ed@gmail.com (T. Edimew) \\ ${ }^{*}$ Corresponding author
}

Bonga Agricultural Research Center, South Agricultural Research Institute (SARI), Hawassa, Ethiopia

\section{To cite this article:}

Tesfu Shegaw, Tewabe Edimew. Assessment on Production, Processing and Marketing Status of Beeswax in Kafa Zone, Southern Nations Nationalities and Peoples Region (SNNPR), Ethiopia. American Journal of Agriculture and Forestry. Vol. 9, No. 4, 2021 , pp. $172-182$. doi: 10.11648/j.ajaf.20210904.12

Received: March 4, 2021; Accepted: April 24, 2021; Published: June 25, 2021

\begin{abstract}
The study was conducted in the three districts of Kafa Zone of Southern Nations Nationalities and Peoples Region being; Chena, Gimbo and Gesha and three peasant associations (PAs) from each district. The main intention was to identify the production, processing and marketing status of beeswax. The districts were purposively selected based on their potential for honey and beeswax production and marketing. The survey data was collected from 239 selected beekeepers and key informants. According to the survey's result, $94.98 \%$ of beekeepers do not practice any processing of honey and sale it in crude form. Only 24 $(13 \%)$ of the respondents practicing collection of beeswax from old combs, 'tej' houses and discarded or broken combs while the majorities $(87 \%)$ of them discarding it as a byproduct. Of those who were collecting beeswax, only 7 (29\%) were processing it for selling to central markets and other local purposes such as foundation sheet making, smearing top bars and traditional candle/'tuaf' making. This implies the trends of collecting, processing and marketing of beeswax is at its very infant stages at beekeepers level. Whereas, local mead houses and cooperatives are considered the major actors engaged in processing and marketing of beeswax. According to personal observation during survey, local mead houses are the major sources where beeswax is readily available year round. However, the overall management practice of beeswax at this market segment is very poor.
\end{abstract}

Keywords: Beeswax, Production, Processing, Marketing, Kafa Zone

\section{Introduction}

Beekeeping is an integral part of agriculture mainly aimed for its valuable products; being honey, beeswax, pollen, royal jelly, bee venom and propolis which mostly used in foods, cosmetics, medicines and engineering industries [3, 22, 26, 27]. It has also inevitable roles for its pollination services [8, $15,18,40]$. The economic benefits of honeybees through pollination is by far exceeds than the worth obtained from their direct products $[22,36]$.

Next to honey, beeswax is considered as a major and oldest product used by human kind [39]. In the ancient times, it had been used for making various paintings, sculptures, adhesives and as medicinal ingredients and healings [14]. Later on with expansion of Christianity, it had extensively being used for candle making for daily ceremonies in churches [29]. Nowadays, in related to the advancement of technologies and modernization, it has been using for producing over 300 industrial products used in various fields including Cosmetics, foods, pharmaceuticals, arts, engineering and industries $[6,11,38]$ resulting for an ever increased demands for this product [26].

Ethiopia is endowed with huge natural resources which favors for the existence of over 10 million honeybee colonies potential for producing huge amount of honey and beeswax [46]. The country owns a potential of producing over 500,000 tons of honey and 50,000 tons of beeswax annually. However, it achieved only about 50,000 tones of honey and 5,542 tons of beeswax which is only about $10 \%$ of its potentials $[23,25]$. . With such an amount, it ranks first in Africa for its both honey and beeswax production and ranks fourth and tenth worldwide for its beeswax and honey 
production respectively $[26,29,43,44]$. Though the country has potentials to meet its beeswax requirements, due to its weak production enhancements and an ever increasing population and urbanization, the domestic demand for beeswax is steadily increasing from time to time to the extent competing the export level [21,41]. Even though the export trends of beeswax is steadily increasing, available export report shows that the mean export level of last eight years (2009-2016) is only 351 tons which is below $10 \%$ of its mean annual production $(5,542$ tons) $[4,23]$. Due to its stability and attractiveness, beeswax is the only animals' product competing to the world market and has been used as a main trading commodity with long lasting cultural values in Ethiopia [2, 7, 27, 42, 47].

Even though small-scale beekeepers are the major sources of beeswax, the trend of producing beeswax from crude honey is undertaken by very few individuals. As a result, local mead houses where about $80 \%$ of the total honey produce goes; considered as the major sources of beeswax in the country $[29,50]$. The average yield of beeswax to be obtained from traditional and modern beehives is estimated to be $8-10 \%$ and $0.5-2 \%$ of its honey yield respectively [31]. This revealed the high coverage of traditional hives coupled with availability of potential bee forages are considered as golden opportunities for the production of huge amount of beeswax [26].

Kafa zone is one of the areas with huge and core forest places of the country where a predominant number of honeybee colonies managed in traditional hives. It covers about $40 \%$ of the regional potentials producing over $132,041.4 \mathrm{~kg}$ of beeswax [19]. As most parts of the country, beekeeping is mainly aimed with obtaining honey and little attention is given for beeswax production. Hence, the aim of this study was to assess the current status of production, processing, handling practices and marketing of beeswax in the studied areas and identifying major constraints and opportunities for production and marketing of beeswax in order to propose the way forward.

\section{Materials and Methods}

\subsection{Description of the Study Areas}

Kafa zone is one of the9zones found in Southern Nations Nationalities and Peoples Region (SNNPR) of Ethiopia; situated at $6^{\circ} 14^{\prime} 28^{\prime \prime}$ to $8^{\circ} 7^{\prime} 11^{\prime \prime} \mathrm{N}$ latitude and $35^{\circ} 26^{\prime} 37^{\prime \prime}$ to $36^{\circ} 47^{\prime} 28^{\prime \prime}$ E longitude covering an area of 10,602.7 sq.km. The population size of the zone is estimated to be $1,102,278$ (541,682 male and 560,596 female); of whom 963,852 (87\%) are rural inhabitants. The agro ecological classification of the zone includes $11.64 \%$ (Highlands), 59.45\% (mid lands) and $28.91 \%$ (low lands). The area receives almost a year round rain falls with major rainy seasons occurring through March to October. The mean annual rainfall of the zone ranges from 1000 to $2200 \mathrm{~mm}$ and the minimum and maximum temperature of the zone is 10.1 and $27.5^{\circ} \mathrm{C}$ respectively [20, $24,45]$.

Kafa zone includes ten administrative districts; namely, Gesha, Chena, Gimbo, Menjieo (Adiyo), Tello, Cheta, Bita, Gewata, Saylem, Decha and one zonal administrative town (Bonga) (Figure 1).

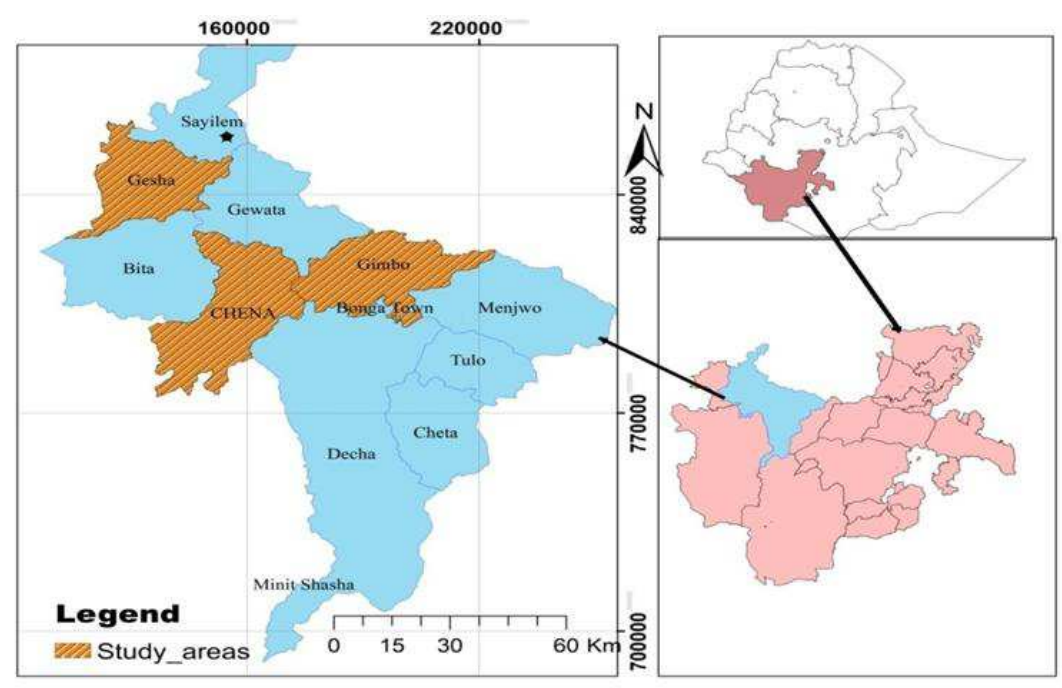

Figure 1. Map of study areas.

\subsection{Study Areas and Sample Respondents Selection}

Three Districts, being Chena, Gimbo and Gesha and three peasant associations/kebeles/ were purposively selected based on their production and marketing potentials of honey and beeswax. Respondent beekeepers were randomly selected using Yamanes's Sample size determination method
[49]; described in equation below (1).

$$
S S=N / 1+N e^{2}
$$

Where; $\mathrm{SS}=$ Required Sample size; $\mathrm{N}=$ Total population; $\mathrm{e}=$ margin of error $(10 \%)$

Accordingly, a total of 239 respondents were sampled 
from nine selected kebeles (PAs) comprising a total of 330 beekeepers (Table 1). In addition, key informants participating in honey and beeswax value chains were also incorporated for collecting survey data.

Table 1. Number of respondent beekeepers.

\begin{tabular}{llll}
\hline District & PAs & Total Beekeeper & Sampled Beekeepers \\
\hline \multirow{3}{*}{ Gesha } & Denity & 32 & 24 \\
& Yeshitweri & 42 & 30 \\
& Didifa & 34 & 25 \\
& Wanabola & 30 & 23 \\
Chena & Dimbira & 46 & 32 \\
& Weshi & 39 & 28 \\
& Tulla & 33 & 25 \\
Gimbo & Shomba & 27 & 21 \\
& Yeyibtu & 45 & 31 \\
& & 330 & 239 \\
\hline
\end{tabular}

\section{Result and Discussion}

\subsection{Socio Economic Characteristics of the Respondents}

Of the total 239 respondents, $228(95.39 \%)$ of them were male and $11(4.61 \%)$ were females. The age distribution $($ Mean \pm SD) of respondents was $39.92 \pm 8.27$; 39.01 \pm 8.45 ; $37.7 \pm 8.53$ years for Chena, Gimbo and Gesha districts respectively. The overall age (Mean $\pm \mathrm{SD}$ ) of studied areas was found to be $38.91 \pm 8.43$ years ranging from 18 to 72 years. According to survey result on age distribution of the respondents, about $72 \%$ of the respondents were found within in a range of 18 to 45 years; about $24 \%$ of them within 46 to 60 years and $4.4 \%$ are more than 60 years of age (Table 2). This revealed the predominant numbers of beekeepers are found within the range of younger age groups.

Table 2. Sex and Age group respondents.

\begin{tabular}{|c|c|c|c|c|c|}
\hline \multirow{2}{*}{\multicolumn{2}{|c|}{$\begin{array}{l}\text { House Hold } \\
\text { Characteristics Variables }\end{array}$}} & \multicolumn{4}{|c|}{ Districts (frequency and percentage) } \\
\hline & & Chena & Gimbo & Gesha & Over all \\
\hline \multirow{3}{*}{ Sex } & Male & $79(95.18 \%)$ & $75(97.4 \%)$ & $74(93.67 \%)$ & $228(95.40 \%)$ \\
\hline & Female & $4(4.82 \%)$ & $2(2.6 \%)$ & $5(6.33 \%)$ & $11(4.60 \%)$ \\
\hline & Total & $83(100 \%)$ & $77(100 \%)$ & $79(100 \%)$ & $239(100 \%)$ \\
\hline \multirow{4}{*}{ Age } & Mean \pm SD & $39.92 \pm 8.27$ & $39.01 \pm 8.45$ & $37.75+8.53$ & $38.91+8.43^{\mathrm{NS}}$ \\
\hline & Range & $25-67$ & $20-65$ & $18-72$ & $18-72$ \\
\hline & $18-45$ & $52(62.65 \%)$ & $56(72.73 \%)$ & $63(79.75 \%)$ & $171(71.55 \%)$ \\
\hline & 61and above & $2(2.41 \%)$ & $4(5.19 \%)$ & $5(6.33 \%)$ & $11(4.60 \%)$ \\
\hline
\end{tabular}

\subsection{Colony Holding of Respondents}

The household colony holding (Mean \pm SD) of the study districts were $15.84 \pm 12.69,16.88 \pm 9.07$ and $21.53 \pm 10.92$ for Chena, Gimbo and Gesha districts respectively (Table 4). There is significant variation of colony holding among study districts at $\mathrm{p}<0.05$. Accordingly, Gesha district has significantly higher colony holding than Gimbo and Chena districts (Table 4). The mean colony holding of the area was found to be $18.05 \pm 11.27$ (Table 4). Similarly comparable result, 15 colonies was also reported [5]. However, it is somehow greater than the mean colony holding of Jima and Illubabor zones which was reported to be $10.3 \pm 2$ and $10.7 \pm 4.3$ respectively [48]. According to Figure 2, colony holding of the respondents in the studied areas ranges from 2 to 92 and about $45 \%$ of the respondents own over fifteen colonies.

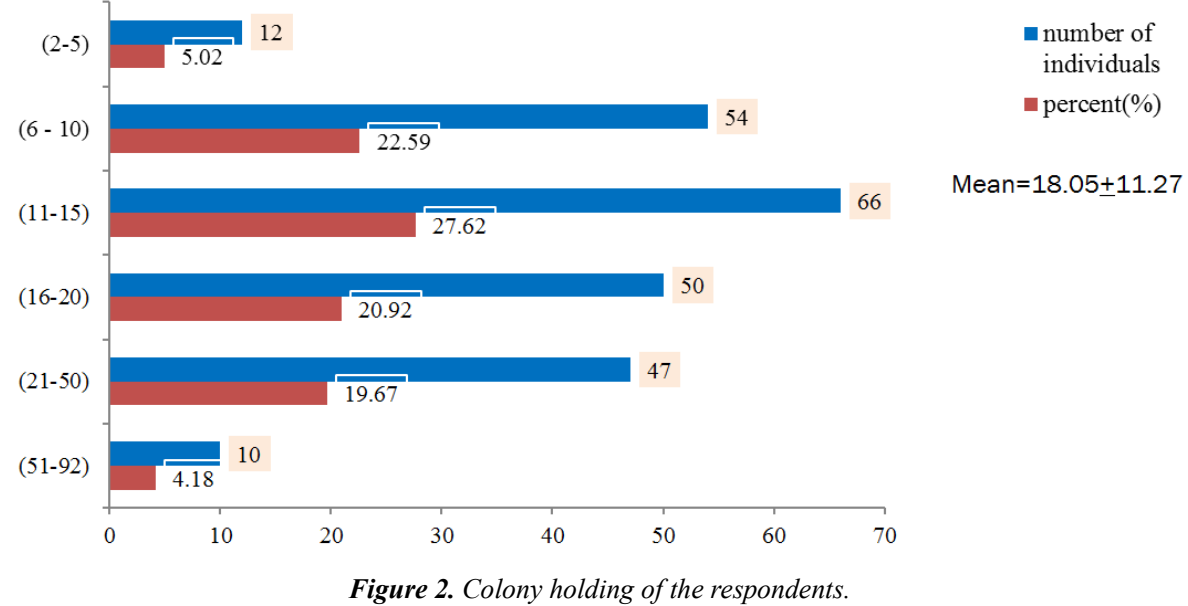

\subsection{Beekeeping Practices}

\subsubsection{Beekeeping Experiences of the Respondents}

Despite the availability of favorable environments and technologies, beekeeping may not be successful unless accompanied with apt knowhow and experiences [17].

According to Figure 3, about $59 \%$ of the of the respondents have over 10 years of beekeeping experiences and about $41 \%$ have less than 10 years of experience. The overall beekeeping 
experiences (Mean $\pm \mathrm{SD}$ ) of the respondents was found to be $13.41 \pm 7.56$ years ranging from 2 to 45 years. Similarly, the beekeeping experience of the area was reported to be $11.89 \pm 3.95$ and $16.17 \pm 6.88$ years respectively [5 and 32]. It is also similar with the experience of beekeepers in Jima and Illubabor zone, which was reported to be $13.51 \pm 6.58$ [48]. The result indicates, even though beekeeping is undertaken in traditional ways, it is considered as long lasting practice in supporting the livelihood of most communities of the areas. Similarly, previous studies also declared that also declared that beekeeping has long been part and parcel of the socio cultural system of South and South western parts of Ethiopia [45 and 51].

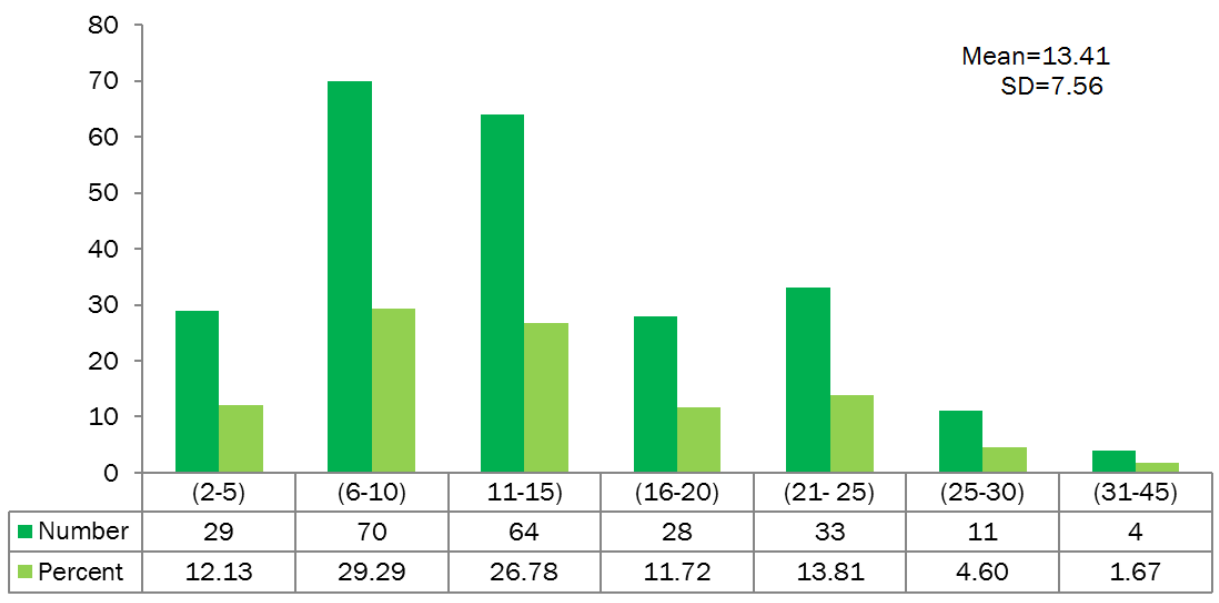

Figure 3. Beekeeping Experiences of respondents.

\subsubsection{Reasons for Engagement in Beekeeping}

The need for income sources is the main reason for the engagement of most of respondents in beekeeping activity followed by home consumption, hobby, and training and other supports taking the second, third and fourth ranks respectively (Table 3). Various studies acknowledged that in related to the huge floral resources, beekeeping is mainly aimed with honey production which is used as the major immediate income sources for most communities of the areas
[29, 30 and 37]. To this fact, over $50 \%$ of the households' income reported to be obtained from beekeeping [5]. During survey, 24 (10.04\%) individuals were found to obtain almost all of their livelihood needs merely from the sale of honey crop. According to few beekeepers replied that training and input supports provided by governmental and nongovernmental Organizations increased their awareness and motivation to be engaged in beekeeping (Table 3 ).

Table 3. Reasons for engagement in beekeeping.

\begin{tabular}{|c|c|c|c|c|c|c|}
\hline \multirow{2}{*}{ Reasons for engagement } & \multicolumn{3}{|l|}{ Ranks } & \multirow[b]{2}{*}{ Total } & \multirow[b]{2}{*}{ Index } & \multirow{2}{*}{ Rank } \\
\hline & $1^{\text {st }}$ & $2^{\text {nd }}$ & $3^{\text {rd }}$ & & & \\
\hline Income & $206(81.42)$ & $33(30.56)$ & - & $239(59.01)$ & 0.67 & 1 \\
\hline Hobby & $15(5.93)$ & $20(18.52)$ & $28(63.64)$ & $63(15.56)$ & 0.11 & 3 \\
\hline Home consumption & $24(9.49)$ & 49 (45.37) & $13(29.55)$ & $86(21.23)$ & 0.18 & 2 \\
\hline Training \& Other supports & $8(3.16)$ & $6(5.56)$ & $3(6.82)$ & $17(5.6)$ & 0.04 & 4 \\
\hline Total & 253 & 108 & 44 & 405 & 1 & \\
\hline
\end{tabular}

Index $=\operatorname{sum}$ of $\left(3 *\right.$ ranked $1^{\text {st }}+2 *$ ranked $2^{\text {nd }}+1 *$ ranked $\left.3^{\text {rd }}\right)$ for individual reason divided by the sum of $\left(3 *\right.$ ranked $1^{\text {st }}+2 *$ ranked $2^{\text {nd }}+1 *$ ranked $\left.3^{\text {rd }}\right)$ for over all reasons.

()$=$ percent

\subsubsection{Hive Types and Honey Production}

As depicted in Table 4, the majorities of hives in the area are locally made traditional hives followed by movable frame/box hives and transitional hives. Similarly, the mean colony holding of respondents was found to be higher in traditional hives followed by moveable frame hives and transitional hives. However, there was no significant variation in terms of colony holding of respondents between moveable frame hives and transitional at $p<0.05$. (Table 4). According to personal observation during survey, even though there are various factors contributing for the minimum adoption levels of improved hives, inaccessibility to road infrastructure was found to be the most determinant factor. To this fact, over $80 \%$ of the respondents who have improved hives are found in areas approaching to main roads within a distance radius of about three kilometers from the main roads. This might be due to their higher exposurities for various supports and information sharing. The honey yield estimate of the areas by hive types and districts in the below Table 6, depicts that annual productivity of the colonies was significantly different at $(\mathrm{p}<0.05)$ among hive types and study districts. Accordingly, Gesha district has significantly higher yield than Chena and Gimbo districts (Table 5).

The current result is greater than the national report which is 
$5-8 \mathrm{~kg}, 10-15 \mathrm{~kg}$ and $20-25 \mathrm{~kg}$ of crude honey per hive from traditional, transitional and movable frame hives respectively [37]. It is also greater than Goma district which was
$7.20 \pm 0.23 \mathrm{~kg}, 14.70 \pm 0.62 \mathrm{~kg}$ and $23.38 \pm 0.73 \mathrm{~kg}$ from traditional, transitional and movable frame hives respectively [16].

Table 4. Share of honeybee colony holdings by hive types.

\begin{tabular}{|c|c|c|c|c|c|c|c|c|}
\hline \multirow{3}{*}{ Hive types } & \multicolumn{8}{|l|}{ Districts } \\
\hline & \multicolumn{2}{|l|}{ Chena } & \multicolumn{2}{|l|}{ Gimbo } & \multicolumn{2}{|l|}{ Gesha } & \multicolumn{2}{|l|}{ Overall } \\
\hline & Total & $\operatorname{Mean} \pm$ SD & Total & $\operatorname{Mean} \pm$ SD & Total & Mean \pm SD & Total & Mean \pm SD \\
\hline Traditional & $980(75)$ & $11.80 \pm 5.10^{b}$ & $952(73.2)$ & $12.36 \pm 5.57^{b}$ & $1300(76)$ & $16.46 \pm 6.12^{\mathrm{a}}$ & $3232(74.88)$ & $13.52 \pm 5.95$ \\
\hline Transitional & $151(11.5)$ & $1.82 \pm 5.52$ & $150(11.5)$ & $1.95 \pm 3.38$ & $156(9.2)$ & $1.97 \pm 3.99$ & $457(10.59)$ & $1.91 \pm 4.40^{\mathrm{NS}}$ \\
\hline Movable frame hives & $184(14)$ & $2.22 \pm 5.58$ & $198(15.2)$ & $2.57 \pm 3.99$ & $245(14.4)$ & $3.10 \pm 5.46$ & $627(14.52)$ & $2.62 \pm 5.07^{\mathrm{NS}}$ \\
\hline Total & 1315 & $15.84 \pm 12.69^{b}$ & 1300 & $16.88 \pm 9.07^{\mathrm{b}}$ & 1701 & $21.53 \pm 10.92^{\mathrm{a}}$ & 4,316 & $18.05 \pm 11.27$ \\
\hline
\end{tabular}

*Letters with different superscript across rows indicates significant difference of hive numbers among districts; () indicates percent

Table 5. Honey yield based on hive types and districts.

\begin{tabular}{|c|c|c|c|c|c|c|c|c|c|c|c|}
\hline \multirow{3}{*}{ Districts } & \multicolumn{11}{|c|}{ Hive types } \\
\hline & \multicolumn{3}{|c|}{ Traditional } & \multicolumn{3}{|c|}{ Transitional } & \multicolumn{3}{|c|}{ Movable frame } & \multicolumn{2}{|c|}{ Over all } \\
\hline & $\begin{array}{l}\text { Total } \\
\text { Hives }\end{array}$ & $\begin{array}{l}\text { Total Yield } \\
(\mathrm{Kg})\end{array}$ & $\begin{array}{l}\text { Yield/ hive } \\
(\text { Mean } \pm \text { SD })\end{array}$ & $\begin{array}{l}\text { Total } \\
\text { hives }\end{array}$ & $\begin{array}{l}\text { Total Yield } \\
\text { (kg) }\end{array}$ & $\begin{array}{l}\text { Yield/hive } \\
(\text { Mean } \pm \text { SD) }\end{array}$ & $\begin{array}{l}\text { Total } \\
\text { hives }\end{array}$ & $\begin{array}{l}\text { Total Yield } \\
\text { (kg) }\end{array}$ & $\begin{array}{l}\text { Yield/hive } \\
(\text { Mean } \pm \text { SD })\end{array}$ & $\begin{array}{l}\text { Total } \\
\text { hives }\end{array}$ & $\begin{array}{l}\text { Total yield } \\
\text { (Kg) }\end{array}$ \\
\hline Chena & 980 & 7,703 & $7.86 \pm 2,16^{\mathrm{b}}$ & 151 & 39,2411 & $14.85 \pm 1.8^{\mathrm{b}}$ & 184 & 4762 & $25.88 \pm 1.85^{b}$ & 1315 & 404,876 \\
\hline Gimbo & 952 & 7,759 & $8.15 \pm 2.14^{b}$ & 150 & 2279 & $15.19 \pm 2.78^{b}$ & 198 & 5215 & $26.34 \pm 2^{\mathrm{b}}$ & 1300 & 15253 \\
\hline Gesha & 1300 & 11,906 & $9.02 \pm 2.53^{\mathrm{a}}$ & 156 & 2,753 & $17.65 \pm 2.42^{\mathrm{a}}$ & 245 & 7093 & $28.95 \pm 2.92^{\mathrm{a}}$ & 1721 & 21752 \\
\hline Total & 3232 & 26,955 & $8.34 \pm 2.33$ & 457 & 7,294 & $15.96 \pm 2.62$ & 627 & 17098 & $27.27 \pm 2.74$ & 4336 & 441,881 \\
\hline
\end{tabular}

*Letters with different superscripts within columns indicates significant variation of honey yield among districts

\subsubsection{Honey Processing}

Honey processing is imperative to maximize the benefits incurred from beekeeping by obtaining additional incomes both from honey and beeswax. In the area, the predominant, about $93 \%$ of the respondents are selling their honey product in crude form.

Of the total 627 box hives counted during the survey, 376 $(60 \%)$ are constructed by local carpentries (Figure 4). Under such types of hives, beekeepers do not use hive frames instead they use top bars and harvesting will takes place in the same manner with that of transitional hives. As shown in Table 6, the majorities of beekeepers who have moveable frame hives sale their honey crop in a crude form. Whereas, very few of them processing their honey using honey extractor. Very few individuals practicing straining honey basically for the purposes of home consumption, sale, as well as family gifts (Table 6). This indicates, processing of honey at beekeepers level is not common in the areas.

As depicted in Table 5, the total honey yield of respondents was estimated to be $441,881 \mathrm{~kg}$. Hence, the amount of beeswax to be obtained would be $35,350.5$ to $44,188 \mathrm{~kg}$ (i.e. $8-10 \%$ of crude honey yield). Based on the current local prices of beeswax (200 EB or 7 US\$), the amount of income would be $7,070,100$ to $8,837,600 \mathrm{~EB}$ or $1,010,014$ to $1,262,514$ US\$. This revealed it would be a huge economic losses when reckoned country wise. Lack of awareness, , considering as it will reduce the amount of honey yield, lack of processing materials, small production level, and consumers preferences were are listed to be the major reasons for not processing their honey (Table 6). Lack of straining materials and skill, knowledge gap on how to strain, Consumers preference were reported to be the major constraints for processing of honey at Guji Zone in order of their importance [10]. On the other study in south Wollo zone indicated that lack of awareness, lack of materials, consumers' preference, small production and considering as it will reduce the amount of honey were reported to be the major reasons for not processing honey in order of their importance [1]. Similarly, considering as it will reduce the amount of honey (55\%), Lack of materials (24.5) and lack of knowledge $20.5 \%$ were listed as the core reasons for not straining honey in Haramaya district [9].

Table 6. Honey processing.

\begin{tabular}{|c|c|c|}
\hline Parameters & Freq. & $\%$ \\
\hline $\begin{array}{l}\text { Individuals straining honey from traditional/transitional } \\
\text { hives }\end{array}$ & 12 & 5.02 \\
\hline $\begin{array}{l}\text { Individuals not straining honey from traditional } \\
\text { /transitional hives }\end{array}$ & 227 & 94.98 \\
\hline \multicolumn{3}{|l|}{ Purposes of straining honey } \\
\hline For home consumption & 12 & 48 \\
\hline For sale & 9 & 36 \\
\hline For family gifts & 4 & 16 \\
\hline Total & 25 & 100 \\
\hline \multicolumn{3}{|l|}{ Materials used for straining } \\
\hline Honey presser & 10 & $83 \%$ \\
\hline Sieves & 2 & $7 \%$ \\
\hline \multicolumn{3}{|l|}{ Reasons for not straining } \\
\hline Lack of awareness & 107 & $31.47(1)$ \\
\hline Lack of materials & 78 & $22.94(3)$ \\
\hline Consumers preference & 25 & $7.35(5)$ \\
\hline Reduces the amount of honey & 85 & $25.00(2)$ \\
\hline Small production & 45 & $13.24(4)$ \\
\hline Total & 340 & 100 \\
\hline $\begin{array}{l}\text { Individuals using honey extractor for their movable } \\
\text { frame hives }\end{array}$ & 7 & 9.72 \\
\hline $\begin{array}{l}\text { Individuals not using honey extractor for their movable } \\
\text { frame hives }\end{array}$ & 65 & 90.28 \\
\hline Total respondents who have moveable frame hives & 72 & 100 \\
\hline
\end{tabular}

() denotes ranks of reasons for not straining honey 


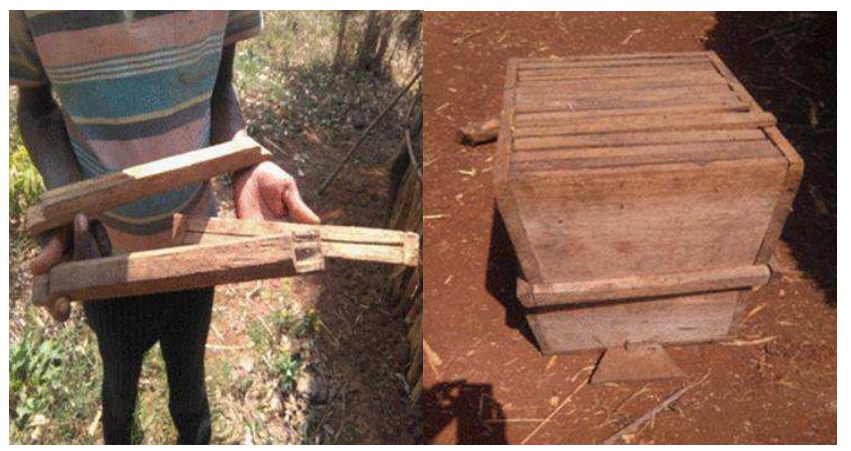

Figure 4. Locally constructed box hive.

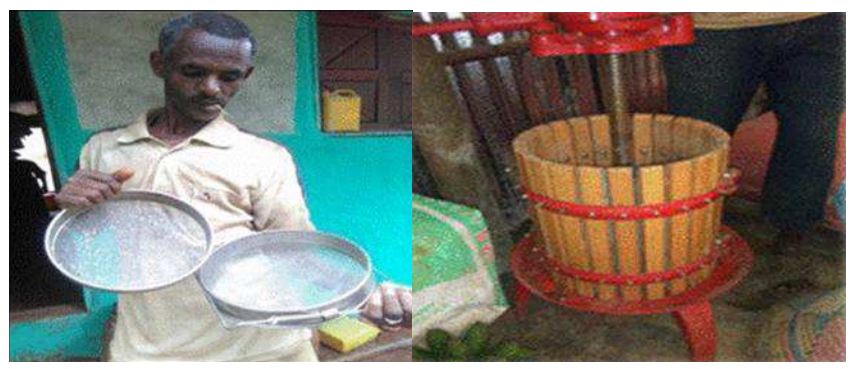

Figure 5. Some of honey processing/extracting materials at beekeepers level.

\subsection{Training and Other Supports}

As honeybees are very complex and wild creatures, detail knowhows about their nature and manipulation skills are paramount to maintain them and obtaining better rewards [36]. To this fact, the less adoption of technologies are partly emanating from their misuses. Hence, training and regular followups are very imperative to maximize the benefits from the sub sector. In the areas Only about quarter of the respondet have got training on the general beekeeping practices and post harvest handling (Table 7). for an avage of about 4.15 dates. Similarly, lack of training and technical supports, shortages of skilled man power were reporteed to be some of the major constraint of beekeepers in the areas [5].

\section{Table 7. Training.}

\begin{tabular}{lll}
\hline Parameters & freq. & \% \\
\hline Individuals who have got any trainn before & 63 & 26.36 \\
Individuals who have not got any training & 176 & 73.64 \\
Name of organization who give training & & \\
BoA/Bo Livestock and fishery dev't & 19 & 15.57 \\
KFBPDMU & 7 & 5.74 \\
AGP & 30 & 24.59 \\
Aspire & 13 & 10.66 \\
HBRC & 3 & 2.46 \\
Apinec & 12 & 9.84 \\
Unknown & 38 & 31.15 \\
Total & 122 & 100 \\
\hline
\end{tabular}

The zone has various governmental and non governmental stake holders taking part in supporting beekeeping subsector. Of which Kafa Forest Bee Products Development And Marketing Cooperative Union (KFBPDMU) and Apicec Agro industry PLC are the major ones providing trainings, inputs, credit services and market facilitations for beekeepers. Other organisations; such as Aspire, ATA (Agricultural Transformation Agency), AGP (Agricultural Growth Program), WV (World Vission), NABU (Nature and Biodiversity Conservation Union), (KBCU) Kafa Biosphere Conservation Union providing various supports to beekeepers in line with conserving natural forest biosphere of the areas (Table 7).

\subsection{Beeswax Production, Processing and Marketing}

\subsubsection{Uses of Beeswax}

Beeswax has a numerous economic values worldwide particularly in industrially developed countries for making various products. However, in developing countries like Ethiopia, its benefit is limited for local purposes only [2]. In the country, the greater amount of beeswax is used for making traditional 'tuaf'/candles which has been used for daily ceremonies for Ethiopian Orthodocs churches. In the studied areas, beeswax has been used for smoking bait hives, making foundation sheets, making candle/'tuaf', for smearing top bars and for baking 'enjera'/'masesha' in order of the frequency of respondent. However, a considerable number of individuals do not know any values of the beeswax and mostly discarding it as byproducts (Table 8 ).

Table 8. Uses of beeswax in the studied areas.

\begin{tabular}{lll}
\hline Uses of Beeswax & Freq & \% \\
\hline To smoke bait hives & 179 & 57.93 \\
For making foundation sheets & 31 & 10.03 \\
For making candle or 'Tuaf' & 24 & 7.77 \\
For baking 'injera'/Masesha' & 9 & 2.91 \\
For Smearing top bars & 17 & 5.50 \\
Don't know any values & 49 & 15.86 \\
Total & 309 & 100 \\
\hline
\end{tabular}

\subsubsection{Beeswax Production and Collection}

Of the total 239 respondents, only 24 (10.04\%) of them are practicing collection of beeswax from absconded colonies, broken and discarded combs, empty combs during harvesting, from extracted honey, left over after consumption of crude honey and from /'tej' houses (Table 9). Lack of awareness, small production, market problems, lack of processing skills, Lack of processing materials, lack of knowhow about its economic benefits and lack of interests are the major constraints for beeswax collection in the studied areas in the order of their importance. (Table 9). Similarly, studies in Hadiya zone indicated that lack of awareness about the product lack of beeswax market, lack of processing skill and processing materials are major

reasons for beeswax collection [28]. Study in South Wollo indicated that lack of awareness, knowledge gap about its economical benefits and market problems were found to be the major constraints of beeswax production [1]. Other study at Haramaya district revealed that lack of knowhow, lack of processing skills, lack of processing materials and lack of markets were also reported to be the core problems for the collection of Beeswax [9]. 
Table 9. Beeswax collection

\begin{tabular}{lll}
\hline Parameters & Freq & \% \\
\hline Individuals who are collecting beeswax & 24 & 13.33 \\
Individuals who are not collecting beeswax & 156 & 86.67 \\
sources for beeswax collection & & \\
From Absconded colonies & 24 & 41.38 \\
From broken, discarded/old combs & 17 & 29.31 \\
Empty combs during harvesting & 13 & 22.41 \\
leftovers after consuming the honey & 3 & 5.17 \\
Collection from 'tej' houses & 1 & 1.72 \\
Total & 58 & 100 \\
Reasons for not collecting & & \\
Small production & 137 & $22.28(2)$ \\
Lack of processing skills & 77 & $12.52(4)$ \\
Lack of processing materials & 62 & $10.08(5)$ \\
Lack of market & 112 & $18.21(3)$ \\
Lack of awareness & 162 & $26.34(1)$ \\
Lack of knowhow about its economic value & 48 \\
Lack of interests & 17 & $7.80(6)$ \\
Total & 615 & $2.76(7)$ \\
\hline
\end{tabular}

() indicates ranking of reasons for not collecting beeswax.

\subsubsection{Beeswax Processing and Storage}

The beeswax should be processed as soon as possible after collection and stored in clean, cool and dry places in wrapping papers, in containers made of stainless steels, glasses or plastics for best preservation of its color and aroma [12 and 33]. From the total of 24 individuals who collect the beeswax, only $7(29.17 \%)$ of them practicing processing beeswax. The rest 17 (70.83\%), merely using the crude waxes for local purposes mainly for smoking bait hives. The beekeepers use the processed beeswax for smearing top bars, making foundation sheets and selling purposes. (Table 10). The ways of storages is significantly varying between the wax processers and non processers. Accordingly, non processing beekeepers will not bothering about the ways of its storages as it is only used for local purposes. Beekeepers store beeswax for shorter times with curiously before processing and storing longer by forming it in block forms. They also use various storage mechanisms and materials to protect its deterioration such as by keeping in aerated places, using fertilizer bag, using plastic materials (Table 10). Wax moths are the major threats of beeswax. It can be prevented by melting the raw beeswax and storing in cool, light and airy places, treating with Bacillus thuringiensis, sulphur, acetic acids and formic acids [13]. Beekeepers in the study areas will reduce the wax moth attacks by placing the beeswax in aerated places, processing the crude wax and soaking in the water. Whereas, mixing with table salt $(\mathrm{NaCl})$ is also practiced by some 'tej' houses to prevent wax moth attacks.

Table 10. Beeswax processing and storages for beekeepers and processors.

\begin{tabular}{|c|c|c|}
\hline Beeswax processing methods & Freq. & $\%$ \\
\hline Sack extraction & 7 & 29.17 \\
\hline No processing & 17 & 70.83 \\
\hline Total & 24 & 100 \\
\hline \multicolumn{3}{|l|}{ purposes of processed beeswax } \\
\hline Selling & 2 & 20 \\
\hline For making foundation sheets & 3 & 30 \\
\hline For smearing top bars & 5 & 50 \\
\hline Total & 10 & 100 \\
\hline \multicolumn{3}{|l|}{ Duration of storing beeswax } \\
\hline For Beekeepers Storing up to one week before processing and for up to two years after processing and molded & 1 & 4.17 \\
\hline Storing up to two weeks before processing and for unlimited times if kept in aerated place after processing in block form & 3 & 12.50 \\
\hline More than two months before processing and for unlimited times if placed in aerated places and periodically soaked in water & 2 & 8.33 \\
\hline Storing up to one month before processing and up to $2-3$ years after processed /molded/ & 1 & 4.17 \\
\hline For more than two years without processing & 2 & 8.33 \\
\hline I don’t know & 1 & 4.17 \\
\hline For one year without processing & 4 & 16.67 \\
\hline Immediately using for smoking hives & 10 & 41.67 \\
\hline Total & 24 & 100 \\
\hline \multicolumn{3}{|l|}{ For cooperatives } \\
\hline For up to one week before processing and up to 3 months after processing and molded & 1 & 50 \\
\hline From 1 to 2 weeks before processing and 0.5 -1year after processing & 1 & 50 \\
\hline Total & 2 & 100 \\
\hline Materials used for storing beeswax & & \\
\hline
\end{tabular}




\begin{tabular}{|c|c|c|}
\hline Beeswax processing methods & Freq. & $\%$ \\
\hline \multicolumn{3}{|l|}{ For Beekeepers } \\
\hline Fertilizer bag & 7 & 29.17 \\
\hline Keeping at aerated places without containers & 12 & 50.00 \\
\hline Plastics & 1 & 4.17 \\
\hline Any materials & 4 & 16.67 \\
\hline Total & 24 & 100 \\
\hline \multicolumn{3}{|l|}{ For cooperatives } \\
\hline Fertilizer bag or sacks & 1 & 25 \\
\hline Putting at aerated and clean rooms & 2 & 50 \\
\hline Wrapping with plastics & 1 & 25 \\
\hline Total & 4 & 100 \\
\hline \multicolumn{3}{|l|}{ Source of beeswax for movable frame hives } \\
\hline Agricultural office & 2 & 4.08 \\
\hline Own sources & 4 & 8.16 \\
\hline Own and agricultural office & 1 & 2.04 \\
\hline No use of wax for frame hives & 42 & 85.71 \\
\hline Total (having frame hives) & 49 & 100 \\
\hline
\end{tabular}

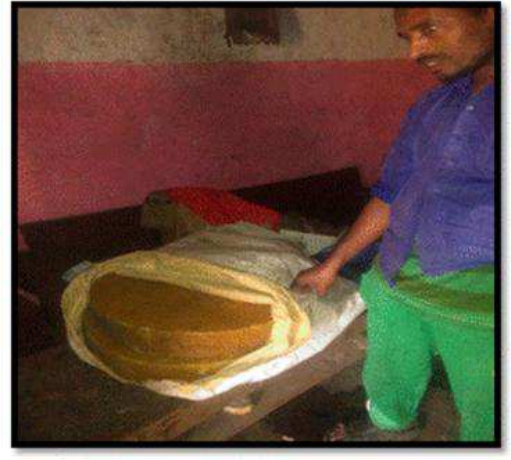

(a)

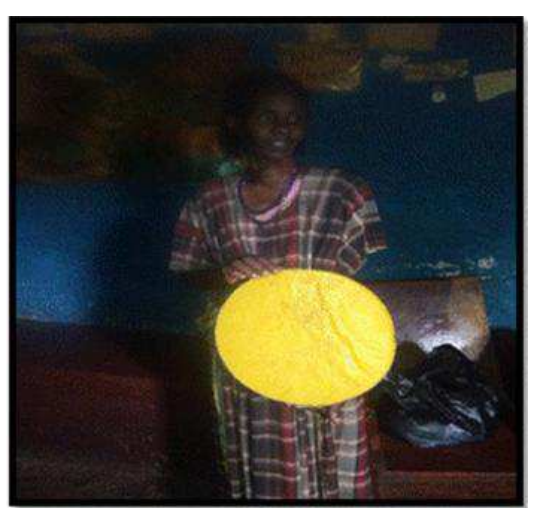

(b)

Figure 6. Beeswax produced by beekeepers (a-Chena district and b- Gimbo district).
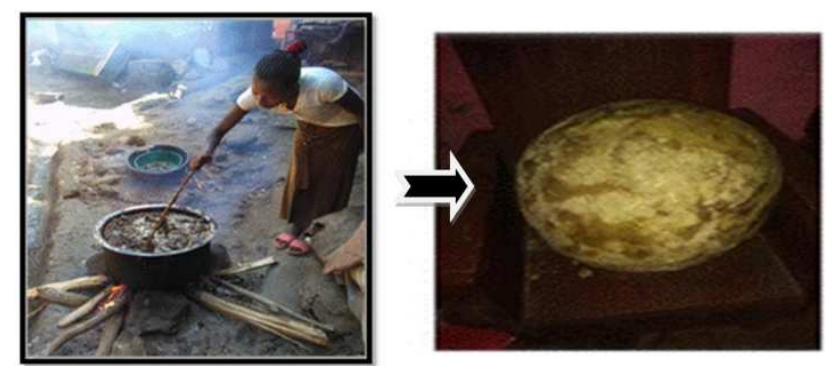

Figure 7. Beeswax production at local mead /'Tej'/ houses (Chena district).

\subsubsection{Beeswax Adulteration}

Table 11. Adulteration of beeswax in the studied areas.

\begin{tabular}{lll}
\hline Individuals' responses on adulteration & Freq & \% \\
\hline There is adulteration practice in the area & 5 & 2.78 \\
$\begin{array}{l}\text { There is no adulteration practice in the area } \\
\text { Types of adulterators }\end{array}$ & 175 & 97.22 \\
'Tej' houses & 2 & 28.57 \\
Merchants from other areas & 5 & 71.43 \\
Total & 7 & 100 \\
Adulterants used & & \\
'Kocho'lenset (for 'tej' houses) & 2 & 28.57 \\
Animal tallow, candles (for merchants) & 5 & 71.43 \\
Times /Occasions of adulterations & & \\
Has no specific times (for 'tej' houses) & 2 & 100 \\
$\begin{array}{l}\text { Some times when wax bought by agricultural offices, NGOs. } \\
\text { Ways of mixing adulterants }\end{array}$ & 5 & 100 \\
$\begin{array}{l}\text { Mixing the 'kocho' after extracting the wax (for tej houses) } \\
\text { I don't know (for wax from other sources) }\end{array}$ & 2 & 100 \\
$\begin{array}{l}\text { Melting and mixing (for wax from other sources) } \\
\text { Ways of identifying adulterated beeswax }\end{array}$ & 4 & 80 \\
lacks uniformity, bees do not visit (for 'tej' houses cases) & 1 & 20 \\
$\begin{array}{l}\text { Bees do not visit (for both cases) } \\
\text { Sticking to wax molding (for wax from other sources) }\end{array}$ & 2 & 100 \\
Has pungent smell (for 'tej' houses cases) & 5 & 100 \\
\hline
\end{tabular}

Adulteration of beeswax with other foreign materials such as animal tallow, candles, are thought to be a serious and cross cutting issues deteriorating the quality status of beeswax produced in the country [26, 35 and 38]. About $97.22 \%$ of the respondents replied that they do heard/encountered with adulteration of beeswax. However, $2.78 \%$ of them replied that rarely there is a case of adulterated beeswax which is distributed by Agricultural office and at local 'tej' houses (Table 11). Some 'tej' houses will mix beeswax with 'kocho' (a local food prepared by scraping the stem of Enset ventricosum plant and fermenting), by masking it in beeswax blocks to obtain additional incomes by increasing its weight. They mix 'kocho' in small amount which not more than 1 to 4 ratios.

\subsubsection{Beeswax Marketing}

Beeswax is a commodity with prestigious international market value that can be economically beneficial and with pro-poor credentials [8]. Of the total 239 respondent, only 
two of them were engaged in processing beeswax for marketing purposes. They collect the crude beeswax from extracted honey, old combs and empty combs during harvesting, discarded combs from around and from left over after the consumption of crude honey. They regularly processing and depositing the beeswax and selling after certain months when the required amount is gained. According to their responses, lack of regular market access is the core problem to be engaged in it and maximizing their production levels. As a result, they sell their processed beeswax periodically transporting to central markets (Addis Ababa). Annually, they may process 30 to $50 \mathrm{~kg}$ of beeswax. Local mead/'tej' houses are the major sources of crude beeswaxes/"sefef"/ and marketing takes place. Various studies also declared that 'tej' houses are the only major sources of beeswax in the country where it is readily available year round [2, 6, 29 and 31].

According to discussion made with 'tej' houses, there is no formal marketing for beeswax/'sefef". However, there are peoples who are coming from other areas at any times and collecting the crude and semi processed beeswax from 'tej' houses and trading to central markets. The prices for one kilogram of beeswax is ranging from 25 to 40 ETB for crude beeswax/'sefef" and 150-200 ETB for extracted beeswax. The price for beeswax does not have significant variations based on seasons and study districts.

Apinec- is a private company which collects the crude honey from the producers of the areas and its own apiaries; extracting and selling the purified beeswax in the form of blocks or by preparing foundation sheets. Unlike other actors taking part in production, processing and marketing of beeswax, Apinec has better potentialities having modern processing machineries used for extracting beeswax and preparing foundation sheets. It also owns mini laboratory to check the qualities of honey which is going to be packed and sent for central/export markets.

Cooperatives are the other actors who are engaged in processing and marketing of beeswax in the study areas. They collect crude honey from member beekeepers, processing and sending to the union (Kafa Forest Honey Development and Marketing Union) which then conveying to central markets. Of the total 239 respondents during survey, $177(74.06 \%)$ of them are registered as members of the cooperatives while the rest $62(25.94 \%)$ are not members.

\subsubsection{Challenges and Opportunities of Beeswax Production and Marketing}

The area has huge untapped potentiality for beeswax production. The dominant traditional ways of beekeeping, existence of honey and beeswax marketing union which has long term planning to establish cooperatives at each district and existence of private limited processing company (Apinec agro industry) are considered as golden opportunities for the production and marketing of beeswax. However, the current production and marketing status of beeswax is very limited compared to the potentials of the areas. Lack of regular buyers, knowledge gaps about its economic values, lack of market information, lack of trainings and technical supports,, skill and Knowledge gaps about product handling and low prices were considered as the core constraints of beeswax production and marketing identified at beekeepers level with in their order of importance (Table 12). Whereas, shortages of supplies, sustainable market accesses, shortages of processing materials and storage facilities are listed as the core constraints of beeswax production and marketing at processors levels. According to the responses from cooperatives, most of the beekeepers have wishes to be registered as a member of cooperative basically in search of various supports. However, there is a great awareness problem in supplying their products (honey and beeswax) timely to the cooperative.

Similar previous studies stated that despite the efforts done by government and other entities in trying to incentivize beeswax production in the country, lack of market accesses is one of the most striking constraints for those who engaged in production [34].

Table 12. Major challenges of beeswax production and marketing in the study areas.

\begin{tabular}{llll}
\hline Major challenges of beeswax marketing & Freq & Percentage & Ranks \\
\hline Lack of regular buyers & 78 & 24.38 & 1 \\
Lack of market information & 58 & 18.13 & 3 \\
Knowledge gaps about its economic values & 62 & 19.38 & 2 \\
Skill and knowledge gaps about product handling & 40 & 12.5 & 6 \\
Low prices & 38 & 10.33 & 7 \\
Lack of training and other supports & 44 & 11.88 & 5 \\
Total & 320 & 100 & \\
\hline
\end{tabular}

\section{Conclusion and Recommendations}

In related to the abundance of immense natural resources, beekeeping is widely practiced by most inhabitants of the areas serving as major instant income sources for most individuals. Local retailers, whole sellers, 'tej' houses, cooperatives, collectors, private companies, are known to be the major honey and beeswax market chain actors in the areas. However, 'tej 'houses, processors and cooperatives are identified to be the major actors taking part in processing and marketing of beeswax. Irrespective of the hive types used, honey harvesting is commonly undertaken by cutting the combs from the hives or frames. About $93 \%$ of the beekeepers sell their honey in crude forms due to lack of awareness, considering as it will reduce the amount of honey yield, lack of processing materials and small production. Moreover, straining of honey from movable frame hives and use of foundation sheet is practiced by very few individuals. In the areas, only about $13 \%$ of beekeepers are engaged in collection of beeswax from old combs, broken combs, 'tej' houses and leftovers after the consumption of honey. The ways of managing beeswax in general and 'tej' houses in particular is very poor and some 'tej' houses add table salt $(\mathrm{NaCl})$ as preservative against wax moth attacks. Hence, awareness creation on the economic benefits of beeswax, training on the production, processing and handling of beeswax product is very crucial. Establishing and capacitating the cooperatives at local level is also very 
imperative to handle the wastages of the product as well as maximizing their profits. On the other hand, encouraging agents or investors to actively participate on production, processing and marketing of beeswax and introducing and demonstrating some robust beeswax processing technologies is also very important. Moreover, awareness creation and follow-ups on appropriate management aspects of beeswax should be given to producers in general and 'tej' house owners' in particular and the impact of preservatives $(\mathrm{NaCl})$ on the quality aspects of beeswax needs further investigation.

\section{References}

[1] Addisu, B., Asaminew, T., Desalegne, B. and Zeleke, M. (2017). Physicochemical properties of Ethiopian Beeswax, the case of South Wollo zone, Amhara Region. International Journal of Agricultural Science Food Technology, 3 (3): pp 61-66.

[2] Aravindakshan, S., Worku, J., Humayun, K. and Waliul, G. (2010). Exploring the potential of Non-timber Forest products: The Case of Ethiopian Honey Export to Denmark. Munich Personal RePEcArchive Research paper No 35483. http//mpra.ub.uni-muenchen.de/35483/.

[3] ARSD (Apiculture Research Strategy Document) (2000). Apiculture research strategy document. EARO (Ethiopian Agriculture Research Organization).

[4] ATA (Agricultural Transformation Agency) (2017). Ethiopia a taste of origin for Honey and Beeswax. www.tasteoforigins.info.

[5] Awraris, G., Yemisrach, G., Dejen, A. and Nuru, A. (2012). Honey production systems (Apis mellifera L.) in Kaffa, Sheka and Bench-Maji zones of Ethiopia. Journal of Agricultural Extension and Rural Development, 4 (19): pp 528-541. doi: 10.5897/JAERD12.088.

[6] Ayalew, K. (2008). Honey and Beeswax Value Chain of BOAM Programme. Establishment of Apiculture Data Base in Ethiopia. SNV Netherlands Development Organization. Addis Ababa, Ethiopia. Beekeepers in Tigray Region, northern Ethiopia. Momona Ethiopian Journal of Science.

[7] Ayalew, K. (2016). Promotion of Beekeeping in the rural sector of Ethiopia. Proceeding of the Ethiopian Beekeepers Association (EBA), August, 2016.

[8] BfD (Bees for development) (2016). Beekeeping and sustainability. Facts sheet. Retrieved from: www.beesfordevelopment.org

[9] Biressaw, S., Tessema, Z., Moges, D. and Mohammed, A. (2015). Potential and Constraints of Beekeeping among beekeepers in Haramaya District, Eastern Ethiopia. Journal of Veterinary Science, 6: 255.

[10] Birhanu, T. (20016). Constraints and Opportunities of Honeybee Production and Honey Marketing Systems: A Case of Guji and Borena Zone of Oromia State". EC Agriculture 3.3 (2016): 635-645.

[11] Bogdanov, S. (2004a). Beeswax: quality issues today. Bee World, 85 (4), 46-50. Retrieved from: www.ibra.org.uk

[12] Bogdanov, S. (2004b). Quality and standards of pollen and beeswax. Apiacta 38 (2004) pp 334-341.
[13] Bogdanov, S. (2016a). Beeswax: Production, Properties Composition and Control. In The Beeswax Book.

[14] Bogdanov, S. $\left(2016^{\mathrm{b}}\right)$. Bees wax: history, uses and trade. Bee Product Science. Chapter. 2. (www.bee-hexagon net).

[15] Bradbear, N. (2009). NON-WOOD FOREST PRODUCT S: Bees and their role in forest livelihoods. A guide to the services provided by bees and the sustainable harvesting, processing and marketing of their products. Rome, Italy.

[16] Chala, K., Taye, T. and Kebede, D. (2013). Assessment of Honey production and Marketing System in Gomma District, South Western Ethiopia. Greener Journal of Business and Management Studies, Vol. 3 (3), pp. 099-107.

[17] Chala, K., Taye, T., Kebede, D. and Tadele, T. (2012). Opportunities and Challenges of honey production in Gomma district of Jimma zone, South western Ethiopia. Journal of Agricultural Extension and Rural Ddevelopment Vol. 4 (4), pp 85-91.

[18] CLI (Crop Life International) (2013). Role of Pollinators in Agriculture. Fast Facts. Available on: http://www.stepproject.net/files/DOWNLOAD2/pb13981bees-pollinators-review.pdf).

[19] CSA (Central Statistical Agency) (2016). Agricultural sample Survey 2015/2016. Volume 2. Report on Livestock and livestock characteristics (private peasant holdings). Statistical bulletin (583). June 2016, A. A., Ethiopia.

[20] CSA (CentralStatistical Agency) (2017). population projection values of 2017 at zonal and woreda level by urban and rural residence and by sex. Popuation Projection of Ethiopia for all Regions at Woread Level (2014-2017).

[21] EMDIDI (Ethiopian Meat and Dairy Industry Development Institute) (2017). Feasibility Study for the establishment of Honey\& Beeswax Processing Investment.

[22] Espolov, T., Ukibayev, J., Myrzakozha, D., Perez, P. and Ermolaev, Y. (2014). Physical and Chemical Properties and Crystal Structure Transformation of Beeswax during Heat Treatment. Natural Science, 6: 871-877.

[23] FAOSTAT (2016). FAOSTAT data. Statistical Database. Livestock Primary. Retrieved January 29, 2018. h http://www.fao.org/faostat/en/\#data/QL

[24] Friis, N. (1992). Forest and Forest Trees of Northeast Tropical Africa, Their Natural Habitats and Distribution Patterns in Ethiopia, Djibouti and Somalia. Kew Bull. Add. Ser. 15: 1-396.

[25] GDS (Global Development Solutions) (2009). Integrated value chain analyses for honey and beeswax production in Ethiopia and prospects for exports (SNV).

[26] Gemechis, L. (2014). Beeswax Production and Marketing in Ethiopia: Challenges in Value Chain. Agriculture, Forestry and Fisheries, 3 (6): pp 447-451.

[27] Gezahegne, T. (2016). Marketing of honey and bees wax in Ethiopia (past, present and perspective futures). The $8^{\text {th }}$ Ethiopian Beekeepers Association Proceedings. August, 2016, Addis Ababa, Ethiopia.

[28] Haftu, K., and Gezu, T. (2014). Survey on honey production system, challenges and Opportunities in selected areas of Hadya Zone, Ethiopia. Journal of Agricultural Biotechnology and Sustainable Development, vol. 6 (6): pp 60-66. 
[29] Hartmann, I. (2004). " No Tree, No Bee - No Honey, No Money": The Management of Resources and Marginalisation in Beekeeping Societies of South West Ethiopia. In Briding Scales and Epistemologies, Alexandria, March 17 - 20, 2004, (pp. 1-12).

[30] Janet, L. and Adrian, W. (2014). The NTFP-PFM Project, South-West Ethiopia. A discussion of the importance of forest beekeeping and commercial honey and beeswax trade for the sustainable management of natural forests in SW Ethiopia.

[31] Johannes, A. (2005). Strategic Intervention Plan on Honey \& Beeswax Value Chains, August, 2005. SNV Support to Business Organisations and Thier Access to Markets (Boam).

[32] Kasa, T., Gonche, G. and Amenay, A. (2017). Value chain analysis of honey in Kafa and Sheka Zones of SNNPR, Ethiopia.

[33] KEBS (Kenyan Bureau of Standards) (2013). Requirements for natural bees wax. Specification for Natural Bees.

[34] McGill E. (2016). Improving the house hold livelihood with modern beekeeping and honey production in Ethiopia. SIPA's economic and political development. Workshop in development practice (final report for WEEMA international), May 9, 2016.

[35] Meseret, G., and Taye, N. (2017). Assessing the Effect of Adulteration on Honey and Beeswax Quality and Designing Way of Identification in Oromia. International Journal of Research Studies in Biosciences (IJRSB), Volume 5, Issue 8: pp 34-39. August, 2017.

[36] Mutsaers, M., Blitterswijk, H., Van, L., Leven, L., van 't, J., Kerkvliet, V. and Waerdt, V. (2005). Bee products. Properties, Processing and Marketing. In M. Mutsaers (Ed.), Agrodok Series 42. Wageningen, Netherlands.

[37] Nuru, A. (2007a). Atlas of pollen grains of major honey bee flora of Ethiopia. Holeta Bee Research Centre: pp 152.

[38] Nuru, A. (2007b). Physical and Chemical Properties of Ethiopian Beeswax and Detection of Adulteration. Ethiopian Journal of Animal Production (EJAP), 7 (1), 39-48.

[39] Nyau, V., Mwanza, EP., and Moonga, HB. (2013). Physicochemical Qualities of honey harvested from different beehive types in Zambia. African Journal of food, Agriculture, Nutrition and Development, 13 (2).

[40] Samuel, S (2017). Review on Market chain Analysis of honey. Journal of Food Science and Quality management, Vol. 60.
[41] Sarah, D. and Jeroen, V. (2011). The Honey and beeswax Value chain in ethiopia. Multistakeholders plat form contribution to Value chain Development. Case study reports.

[42] Seid, G. and Solomon, L. (2015). Review on Beekeeping Activities, Opportunities, Challenges and Marketing in Ethiopia. Journal of Harmonized Research in Applied Sciences, 3 (4): pp 201-214.

[43] Sisay, F. (2015). Review of Honey Bee and Honey Production in Ethiopia. Journal of Animal Science Advances, 5 (10): pp 1413-1421.

[44] SNV/Ethiopia (2005). Strategic intervention plan on Honey and Bees wax Value chains. August, 2005, Addis Ababa, Ethiopia.

[45] Tefera, B. (2005). Dynamics in the Management of Honey Production in the Forest Environment of Southwest Ethiopia: Interactions between Forests and Bee Management (MSc. Thesis). Forest and Nature Conservation Policy Group Department of Environmental Science Wageningen University, Wageningen. June 2005.

[46] United State Agency for International Development (USAID) (2008). Ethiopia Biodiversity and tropical forests 118/119 Assessment.

[47] United State Agency for International Development (USAID) (2012). Cost Benefit Analysis of Honey Value Chain in Ethiopia. Graduation with resilience to achieve sustainable development GRAD- project Final Report (www.OptimalSolutionsGroup.com).

[48] Welay, K., Tekleberhan, T. (2017). Honey-bee production practices and hive technology preferences in Jima and Illubabor Zone of Oromia Regional State, Ethiopia. ACTA UNIVERSITATISSAPIENTIAE Agriculture and environmental Science, 9 (2017). 31-43.

[49] Yamane, T. (1967). Statistics: An introductory analysis, $2^{\text {nd }}$ Edition, New York: Harper and Row.

[50] Yeshitela, E., Demelash, Z., Hana, T., Tigist, L., Tekeba, E. and Taye, N. (2018). Determination of the proportion of pure beeswax recovered from crude beeswax resources at local honey wine making houses in Ethiopia. Journal of Nutritional Health \& Food Engineering, Volume 8, Issue 3.

[51] Yoshimasa, IT. (2014). Local Honey production activities and their significance for local people: a case of Mountain forest area of southwestern Ethiopia. African Study Monographs, Suppl. 48: 77-97, March 2014. 